\title{
Mechanical Thrombectomy in Patients With Acute Ischemic Stroke: A Comparison of Transradial Versus Transfemoral Cerebral Angiography
}

\author{
Mohammad R. Ghani ${ }^{1}$, Vishal Busa ${ }^{2}$, Ahmed Dardeir ${ }^{2,3}$, Suganya Marudhai ${ }^{4}$, Mauli Patel ${ }^{4}$, Yousif M. \\ Abdelmoneim ${ }^{4,5}$, Ahmad Jan 6, 7 , Noha Eskander ${ }^{8}$ \\ 1. Neurology, California Institute of Behavioral Neurosciences \& Psychology, Fairfield, USA 2. Internal \\ Medicine/Family Medicine, California Institute of Behavioral Neurosciences \& Psychology, Fairfield, USA 3. \\ Department of Physical Medicine and Rehabilitation, Richmond University Medical Center, New York, USA 4. Internal \\ Medicine, California Institute of Behavioral Neurosciences \& Psychology, Fairfield, USA 5. Department of Laboratory \\ Medicine and Pathology, Mayo Clinic, Jacksonville, USA 6. Surgery, California Institute of Behavioral Neurosciences \& \\ Psychology, Fairfield, USA 7. Department of General Surgery and Emergency Services, International Medical Centre, \\ Jeddah, SAU 8. Psychiatry, California Institute of Behavioral Neurosciences \& Psychology, Fairfield, USA
}

Corresponding author: Mohammad R. Ghani, mr92ghani@gmail.com

\begin{abstract}
Stroke is the fourth leading cause of death in the United States and the primary reason for long-term disability. This debilitating condition can be divided into ischemic stroke and hemorrhagic stroke. The former occurs in almost $90 \%$ of all cases and arises from the occlusion of the supplying artery. Over the years, the management of stroke has developed from solely medical treatment to that which combines medical with mechanical treatment. Mechanical thrombectomy (MT) has drawn considerable interest in advanced medicine and is becoming more widely available. The two fundamental techniques in opening an occluded vessel are the transfemoral and transradial approaches. This literature review aims to compare the clinical implications, complication rate, and overall outcome between the transfemoral and transradial approaches in endovascular intervention in patients with acute ischemic stroke. We conducted a literature review on ischemic stroke and searched PubMed and Google Scholar for relevant articles published from January 2010 to March 2020. Mechanical thrombectomy has become the standard of care for patients with brain ischemia. The transradial approach exhibited superiority to the transfemoral route in resolving symptoms, decreased complication rates, and reduced healthcare costs in a subset of patients. In this literature review, the comparison between the two procedures reveals that the outcomes for anterior circulation stroke and posterior vascular system stroke may vary. Further research needs to be conducted to improve procedural skills and decrease technical difficulties, ultimately resulting in improved overall patient outcomes with respect to health and comfort.
\end{abstract}

Received 09/04/2020

Review began 09/23/2020 Review ended 10/07/2020 Published 10/12/2020

\section{(c) Copyright 2020}

Ghani et al. This is an open access article distributed under the terms of the Creative Commons Attribution License CC-BY 4.0., which permits unrestricted use, distribution, and reproduction in any medium, provided the original author and source are credited.
Categories: Neurology, Psychiatry, Neurosurgery

Keywords: acute ischemic stroke, cerebrovascular disease, mechanical thrombectomy, transradial access, transfemoral access

\section{Introduction And Background}

With a prevalence of approximately 3\% in the United States, stroke is the primary reason for long-term disability and the fourth leading cause of death [1]. Stroke can result from a ruptured vessel in the brain (hemorrhagic stroke) or blockage of blood supply (ischemic stroke) due to a thrombus or embolus [2]. Ischemic stroke is the most common type of stroke, comprising $90 \%$ of all cases. The blockage of blood flow limits the delivery of oxygen and nutrients, resulting in damage to or death of the brain cells, becoming permanent if the flow is not restored within a specified timeframe [2,3].

The circulation of the brain has two major arterial divisions, the anterior distribution, and posterior distribution. The anterior circulation supplies $80 \%$ of the brain circulation, arising from internal carotid arteries, whereas the posterior circulation supplies the remaining $20 \%$ of the brain circulation, specifically from vertebral arteries $[4,5]$. The anterior circulation branches into the middle cerebral artery (MCA) and anterior cerebral artery (ACA) [6]. The majority of acute ischemic stroke is due to large vessel occlusion in the anterior circulation, most frequently the internal carotid artery [6,7]. Management of ischemic stroke has advanced from conventional to interventional methods over the past decades, and modalities have been developed for different mechanical treatments. Among them, the commonly used methods are the transfemoral and transradial approaches for endovascular mechanical thrombectomy (MT), which is employed during acute ischemic stroke due to large vessel intracranial occlusion [8]. MT involves the delivery of a device into the affected blood vessel in the brain, typically through a catheter via the femoral artery, which then navigates toward the clot's location within the neurovasculature. This device is also used to capture and remove the clot [9]. MT has become the standard of care in the management of emergent 


\section{Cureus}

large-vessel occlusive strokes.

The brachial, radial, transcervical, and direct carotid arteries are mostly used when access via the femoral artery is not possible. Neuroendovascular procedures are traditionally performed using the common transfemoral approach because of the size and length of endovascular equipment [10]. The transradial method has been extensively used as an alternative to the femoral approach in coronary interventions. Angiography via the transradial route was first described in 1989 by Campeau. This method was subsequently adopted, with its strengths and limitations identified [11]. In 2016, up to $4.5 \%$ of MT procedures in the US were performed via transradial access (TRA). Many studies reported on the benefits of this method, considering the comfort it provides for the patient, cost efficiency, and shortened hospital stay [12].

Over the years, stroke management has evolved from solely medical to combined medical and mechanical treatment. Before proceeding with an intervention, numerous factors have to be considered in determining the approach to implement. This narrative review aims to compare the clinical implications, complication rate, patient comfort, cost-effectiveness, and overall outcome of the transfemoral and transradial approaches to an endovascular intervention in adult patients with acute ischemic stroke [13].

\section{Review}

\section{Method}

We conducted a literature search on PubMed and Google Scholar using the search words "mechanical thrombectomy", "acute ischemic stroke", "transradial angiography", "transfemoral angiography", "endovascular intervention". Reference lists of relevant articles identified using this method were scanned for other studies that were not identified through the electronic search. This resulted in more than 1680 articles in total. We reviewed 56 articles initially and 20 were included for the final reference list based on their relevance to the topics covered in this review. The studies published from January 2010 to March 2020 were included. The search was designed to identify studies regarding endovascular interventions via MT, particularly transradial and transfemoral thromboembolectomy, in patients with stroke. The search was limited to publications in English and studies conducted on humans. Exclusion criteria were interventions other than transradial or transfemoral, studies in another language other than English, non-humans studies, studies done outside the date assigned. The inclusion and exclusion criteria were set, and any disagreement was settled through a discussion.

\section{Results}

Findings from some relevant studies that showed the role of the transradial and transfemoral approaches in the management of ischemic stroke are listed in Table 1.

\begin{tabular}{|c|c|c|c|c|}
\hline $\begin{array}{l}\text { Author and } \\
\text { publication } \\
\text { year }\end{array}$ & Study design & Methodology & Diagnostic criteria & Conclusion \\
\hline $\begin{array}{l}\text { Balami JS, } \\
\text { et al. } \\
(2018)[14]\end{array}$ & $\begin{array}{l}\text { Systematic } \\
\text { review }\end{array}$ & $\begin{array}{l}\text { Included only human studies and } \\
\text { was limited to studies published in } \\
\text { English between January } 2014 \text { and } \\
\text { November } 2016 \text { based on } \\
\text { relevance to the topics covered } \\
\text { "Complications of endovascular } \\
\text { treatment for acute ischemic } \\
\text { stroke: Prevention and } \\
\text { management" in the review. }\end{array}$ & $\begin{array}{l}\text { Frequency of } \\
\text { complications of } \\
\text { mechanical } \\
\text { thrombectomy in } \\
\text { the treatment of } \\
\text { acute ischemic } \\
\text { stroke with an } \\
\text { emphasis on } \\
\text { perioperative } \\
\text { complications. }\end{array}$ & $\begin{array}{l}\text { The risk of complications with sequelae from } \\
\text { mechanical thrombectomy was } \sim 15 \% \text {, and the } \\
\text { transfemoral approach was ineffective. }\end{array}$ \\
\hline $\begin{array}{l}\text { Jolly SS, et } \\
\text { al. (2011) } \\
{[15]}\end{array}$ & $\begin{array}{l}\text { A } \\
\text { randomized, } \\
\text { parallel- } \\
\text { group, } \\
\text { multicenter } \\
\text { trial }\end{array}$ & $\begin{array}{l}\text { A total of } 7021 \text { patients were } \\
\text { enrolled from } 158 \text { hospitals in } 32 \\
\text { countries between June } 6,2006 \text {, } \\
\text { and Nov } 3,2010 ; 3507 \text { patients } \\
\text { were randomly assigned to the } \\
\text { radial access group and } 3514 \text { to } \\
\text { the femoral access group. }\end{array}$ & $\begin{array}{l}\text { Transradial and } \\
\text { transfemoral } \\
\text { approaches. }\end{array}$ & $\begin{array}{l}\text { In this study with } 3507 \text { patients in the radial access } \\
\text { arm vs } 3514 \text { in the femoral access arm. Transradial } \\
\text { coronary angiography and angioplasty were safe, } \\
\text { feasible, and effective with similar results to those of } \\
\text { the transfemoral approach, (HR } 0.49,95 \% \mathrm{Cl} 0.28 \text { - } \\
0.87 ; p=0.015) \text {. }\end{array}$ \\
\hline DC, et al. & $\begin{array}{l}\text { Retrospective } \\
\text { review }\end{array}$ & $\begin{array}{l}\text { A retrospective review of the local } \\
\text { institutional AIS interventional } \\
\text { databases of three tertiary }\end{array}$ & $\begin{array}{l}\text { Feasibility and } \\
\text { safety of transradial } \\
\text { access in the } \\
\text { interventional }\end{array}$ & $\begin{array}{l}\text { Failure of transfemoral access in the endovascular } \\
\text { treatment of AIS was uncommon but led to } \\
\text { unacceptable delays in reperfusion and poor } \\
\text { outcomes. Standardization of benchmarks for access } \\
\text { switches served as a guide for neuro }\end{array}$ \\
\hline
\end{tabular}




\section{Cureus}

\begin{tabular}{|c|c|c|c|c|}
\hline (2016) [16] & & academic centers. & $\begin{array}{l}\text { management of } \\
\text { acute ischemic } \\
\text { stroke. }\end{array}$ & $\begin{array}{l}\text { interventionalists. Transfemoral access was a good } \\
\text { approach for the endovascular treatment of acute } \\
\text { ischemic stroke. Transradial access was effective in } \\
\text { allowing clot engagement. }\end{array}$ \\
\hline $\begin{array}{l}\text { Mendiz } \\
\text { OA, et al. } \\
\text { (2016) [17] }\end{array}$ & Clinical trials & $\begin{array}{l}\text { Clinical and angiographic data of } \\
775 \text { consecutive patients with high } \\
\text { risk for carotid endarterectomy, } \\
\text { treated between } 1999 \text { and } 2016 \text { by } \\
\text { carotid artery stenting with } \\
\text { cerebral protection. }\end{array}$ & $\begin{array}{l}\text { Comparison of the } \\
\text { outcome and } \\
\text { complication rates } \\
\text { of transradial and } \\
\text { transfemoral } \\
\text { carotid artery } \\
\text { stenting. }\end{array}$ & $\begin{array}{l}\text { Mechanical thrombectomy combined with standard } \\
\text { intravenous thrombolysis improved functional } \\
\text { independence in patients with acute cerebral } \\
\text { ischemia, with no evidence of increased mortality. } \\
\text { Bridging therapy should be considered for patients } \\
\text { with large-vessel occlusions of the anterior circulation. }\end{array}$ \\
\hline $\begin{array}{l}\text { Bertrand } \\
\text { OF, et al. } \\
\text { (2010) [18] }\end{array}$ & $\begin{array}{l}\text { Cross- } \\
\text { sectional } \\
\text { study }\end{array}$ & $\begin{array}{l}\text { The survey was officially launched } \\
\text { online on August } 27,2009 \text {, to } \\
\text { collect } 1,000 \text { responses worldwide. }\end{array}$ & $\begin{array}{l}\text { The survey was } \\
\text { conducted from } \\
\text { August } 2009 \text { to } \\
\text { January } 2010 \\
\text { among } 1,107 \\
\text { interventional } \\
\text { surgeons with } \\
\text { extensive } \\
\text { experience in } \\
\text { transradial access } \\
\text { in } 75 \text { countries. }\end{array}$ & $\begin{array}{l}\text { Most respondents who used transradial access were } \\
\text { moderate- or high-volume operators performing }>100 \\
\text { PCls/year. }\end{array}$ \\
\hline $\begin{array}{l}\text { Barros G, } \\
\text { et al. } \\
\text { (2020) [19] }\end{array}$ & $\begin{array}{l}\text { Retrospective } \\
\text { study }\end{array}$ & $\begin{array}{l}\text { A retrospective chart review was } \\
\text { prepared on patients who } \\
\text { underwent cerebral angiography } \\
\text { accessed via the left radial artery in } \\
\text { three institutions from January } \\
2018 \text { to July } 2019 .\end{array}$ & $\begin{array}{l}\text { Technical feasibility } \\
\text { of the left } \\
\text { transradial access } \\
\text { to cerebral } \\
\text { angiography across } \\
\text { three institutions. }\end{array}$ & $\begin{array}{l}\text { Left transradial access in diagnostic and } \\
\text { interventional cerebral angiography was a technically } \\
\text { feasible, safe, and effective alternative when indicated. } \\
\text { It would be preferable for situations in which } \\
\text { pathologic locations or anatomic limitations preclude } \\
\text { the right-sided radial access. }\end{array}$ \\
\hline $\begin{array}{l}\text { Zussman } \\
\text { BM, et al. } \\
\text { (2019) [20] }\end{array}$ & Clinical study & $\begin{array}{l}\text { A subsequent prospective series of } \\
50 \text { consecutive right transradial } \\
\text { diagnostic cerebral arteriograms } \\
\text { were compared with initial } \\
\text { institutional experience using a } \\
\text { procedural staging system. }\end{array}$ & $\begin{array}{l}\text { Prospective data on } \\
\text { the learning curve } \\
\text { for neuro } \\
\text { interventionalists } \\
\text { adopting this } \\
\text { approach are } \\
\text { limited. }\end{array}$ & $\begin{array}{l}\text { Neurointerventionalists overcame the right transradial } \\
\text { learning curve and achieved high success rates and } \\
\text { low crossover rates after performing } 30-50 \text { cases. }\end{array}$ \\
\hline $\begin{array}{l}\text { Jo KW, et } \\
\text { al. (2010) } \\
\text { [21] }\end{array}$ & Clinical trials & $\begin{array}{l}\text { From February } 2007 \text { to October } \\
2009,1,240 \text { cerebral angiography } \\
\text { procedures were performed via the } \\
\text { single center's transradial } \\
\text { approach. }\end{array}$ & $\begin{array}{l}\text { Feasibility, efficacy, } \\
\text { and safety of the } \\
\text { transradial } \\
\text { approach to } \\
\text { cerebral } \\
\text { angiography. }\end{array}$ & $\begin{array}{l}\text { Cerebral angiography via the transradial approach } \\
\text { with minimal risk of morbidity. }\end{array}$ \\
\hline $\begin{array}{l}\text { Chen SH, } \\
\text { et al. } \\
\text { (2019) [22] }\end{array}$ & $\begin{array}{l}\text { A } \\
\text { retrospective } \\
\text { review of } \\
\text { institutional } \\
\text { database }\end{array}$ & $\begin{array}{l}\text { A retrospective review of our } \\
\text { institutional database to identify } 51 \\
\text { patients with challenging vascular } \\
\text { anatomy who underwent } \\
\text { mechanical thrombectomy for } \\
\text { anterior circulation large-vessel } \\
\text { occlusion from February } 2015 \text { to } \\
\text { February } 2018 \text {. }\end{array}$ & $\begin{array}{l}\text { Comparison of } \\
\text { outcomes in } \\
\text { patients who } \\
\text { underwent } \\
\text { mechanical } \\
\text { thrombectomy via } \\
\text { transradial access } \\
\text { versus transfemoral } \\
\text { access }\end{array}$ & $\begin{array}{l}\text { Results demonstrate equivalence in efficacy and } \\
\text { efficiency between transradial access and } \\
\text { transfemoral access for the mechanical thrombectomy } \\
\text { of the anterior circulation large-vessel occlusion in } \\
\text { patients with challenging vascular anatomy. }\end{array}$ \\
\hline
\end{tabular}

\section{TABLE 1: Summary of characteristics from some of the studies included.}

AIS: Acute ischemic stroke; $\mathrm{PCl}$ : percutaneous coronary intervention.

\section{Discussion}

The common femoral artery remains the primary access site for many neuro interventionalists because of the large-caliber size, smooth compression to the femoral head, familiarity with the anatomy of the artery, and broad user experience with different catheters designs [23]. However, this traditional approach has several 
limitations. Anatomic factors such as aortoiliac occlusive disease and ectasia of the aorta, aortic arch, and supra-aortic vessels may hinder angiography and/or increase the risk of an intervention [24]. Other reasons that render the transfemoral approach less favorable than the transradial approach include the risk of complications related to the vascular system: retroperitoneal bleeding, arteriovenous fistulas, lowerextremity ischemia resulting from the dissection or baseline peripheral vascular disease, pseudoaneurysms, and femoral nerve damage [17,25]. Obese patients and those undergoing anticoagulation or antiplatelet therapy had a greater risk for complications with the transfemoral approach. Another disadvantage was that patients needed six hours of flatbed rest after the procedure in the femoral approach unless a percutaneous closure device was used [16].

Access through the transradial route had a vascular complication rate of $0.1 \%-0.2 \%[18,19]$. Other complications that commonly occur with the transradial approach include asymptomatic temporary or permanent radial arterial occlusion, which has an occurrence rate of $5 \%$. This occurrence is attributable to the small size of the radial artery prolonged cannulation, the radial artery diameter's ratio to the outer sheath diameter, and the anticoagulant used during arterial cannulation. Some reports suggest that these major complications stem from the length and large diameter of the introduced catheter. Therefore, avoiding a large and long catheter would prevent such major complications. Radial artery spasm can occur in approximately $10 \%$ of patients despite standardized preventative spasmolytic measures. This low rate is attributable to the collateral circulation of the hands [26]. Iatrogenic blockage of the radial artery is well tolerated in the presence of an intact palmar arcade and a competent ulnar artery. The patency of collaterals was evaluated before intervention by physical exam (Allen Test) and Doppler ultrasound [27]. In a study of 1360 patients, no radial artery occlusions occurred after immediate sheath removal. By contrast, $5 \%$ of the radial arteries became occluded when the sheath was left in place for more than three hours after the procedure [20].

Among the transradial cerebral intervention limitations is a high level of procedural skills required from the operator and the discomfort of performing such a procedure. The reasons the operator less prefers this approach include the training requirement, technical limitations associated with catheter technology, discomfort related to the laboratory staff or setup, apparently lengthy duration of the method, and procedural discomfort [21]. However, consistent learning and the experience of performing around 30-50 radial interventions can improve the skills of interventionalists, enhancing their efficiency and level of comfort with this procedure [28].

The radial artery location also facilitates hemostasis by local compression, minimizing risks for hematoma formation and damage to other structures [22]. Despite the minimal adverse effects associated with the transradial approach, conversion from the transradial to transfemoral access has been reported in $1 \%-7 \%$ of cases. A study reported higher failure rates in the transradial than the transfemoral and brachial routes for percutaneous transluminal coronary angioplasty, which was ascribed to radial artery spasm and narrow vessel caliber. Anatomical variations in the radial artery are not rare occurrences. In one study, almost $7.8 \%$ of 115 participants were found to have variable radial arteries. Variations such as a radioulnar loop, hypoplasia of the radial artery, or stenosis of the radial or brachial artery impede the successful completion of the endovascular procedure without necessarily disqualifying these patients from transradial procedures. The transradial method is also limited by the difficulty of accessing other arch vessels. Femoral access is considered if access to other arch vessels, particularly the contralateral vertebral artery, is needed [29].

About $71 \%$ of patients prefer TRA over the transfemoral route when presented with the option. This preference is attributable to the higher bleeding risk, a higher degree of pain during the procedure, and within hours after the procedure, and lower tolerance for postoperative mobility precautions associated with the transfemoral approach. After a transradial procedure, patients can walk immediately, increasing patient comfort. Decreases in hospitalization time and adverse outcomes associated with TRA also translated into reduced healthcare costs [25].

Another significant advantage of TRA is that it allows the performance of angiography after anticoagulation therapy with increased hemostatic control. Patients with coagulopathies or receiving anticoagulation therapy were suitable candidates for TRA because of their higher risk for bleeding complications with transfemoral approach (TFA), precisely when no closure device was used.

The advantages and disadvantages of TFA and TRA in acute ischemic stroke are summarized in Table $2[18,19,25]$. 


\section{Cureus}

Transradial Approach

Advantages

- Lower morbidity and mortality compared with the transfemoral approach - Low risk of vascular complications - it is the preferable method for a patient on anticoagulant or antiplatelet therapy Low procedural cost - Improved recovery time and early discharge - Less pain with arterial puncture intraoperatively and postoperatively - Presence of collaterals can compensate for radial arterial occlusion - Discontinuation of the nothing-by-mouth restriction shortly after the procedure - Greater patient satisfaction than the transfemoral approach

Disadvantages
- Limited operator experience -
Difficulty of the procedure due to
anatomical variations - Risk of
iatrogenic stenosis - Varying
levels of difficulty depending on
the diameter of the radial artery -
Longer duration compared with
the femoral approach - Technical
limitation attributable to catheter
technology and discomfort
related to laboratory staff/setup

Transfemoral

Approach

Advantages

- Availability of

interventionalist

with experience in

this procedure -

Large femoral

artery diameter -

Known and

manageable

procedural

complications -

Preferable method

in patients with

peripheral arterial

disease
Disadvantages

- Vascular complications,

including bleeding,

pseudoaneurysms, and clot

formation - Extended hospital

stays - Lower patient

satisfaction and higher patient discomfort compared with the transradial approach - Higher procedural costs involved

compared with the transradial approach - Femoral artery is the only source of blood to the leg

TABLE 2: Summary of the advantages and disadvantages of transfemoral access and transradial access in acute ischemic stroke.

\section{Conclusions}

In the last decade, the transradial and transfemoral approaches in ischemic stroke management have been largely studied and drawn significant interest. Although both techniques exhibit efficiency, practicality, and benefits, they also involved complications. In this narrative literature review, we demonstrate the expediency of TRA over TFA for endovascular interventions in patients with ischemic stroke. TRA presents several advantages but also has limitations. Overall, the use of TRA has gained preference by doctors and patients, but TFA remains as the first option in most cases.

\section{Limitations and future directions}

One of the challenges encountered in this study is that the procedures described are not categorized for anterior or posterior circulation stroke. The duration of the complications encountered during either technique was not measured, and the long-term benefits or outcomes were not identified. Moreover, the catheter technique used was not always clear. Accordingly, we recommend conducting further studies to improve the catheter technique and operator procedural skills, leading to improved outcomes in patient health and comfort.

\section{Additional Information \\ Disclosures}

Conflicts of interest: In compliance with the ICMJE uniform disclosure form, all authors declare the following: Payment/services info: All authors have declared that no financial support was received from any organization for the submitted work. Financial relationships: All authors have declared that they have no financial relationships at present or within the previous three years with any organizations that might have an interest in the submitted work. Other relationships: All authors have declared that there are no other relationships or activities that could appear to have influenced the submitted work.

\section{Acknowledgements}

We thank Hassaan Tohid and Pousette Farouk for their guidance in writing this paper and editorial assistance.

\section{References}

1. Ovbiagele B, Nguyen-Huynh MN: Stroke epidemiology: advancing our understanding of disease mechanism and therapy. Neurotherapeutics. 2011, 8:319-329. 10.1007/s13311-011-0053-1

2. Gory B, Eldesouky I, Sivan-Hoffmann R, et al.: Outcomes of stent retriever thrombectomy in basilar artery occlusion: an observational study and systematic review. J Neurol Neurosurg Psychiatry. 2016, 87:520-525. 10.1136/jnnp-2014-310250

3. Roger VL, Go AS, Lloyd-Jones DM, et al.: Heart disease and stroke statistics-2011 update: a report from the American Heart Association. Circulation. 2011, 123:e18-e209. 
4. Chandra A, Li WA, Stone CR, Geng X, Ding Y: The cerebral circulation and cerebrovascular disease I: anatomy. Brain Circulation. 2017, 3:45-56.

5. Bosmia AN, Hogan E, Loukas M, Tubbs RS, Cohen-Gadol AA: Blood supply to the human spinal cord: part I. Anatomy and hemodynamics. Clin Anat. 2015, 28:52-64. 10.1002/ca.22281

6. Makowicz G, Poniatowska R, Lusawa M: Variants of cerebral arteries-anterior circulation. Pol J Radiol. 2013, 78:42-47.

7. Rennert RC, Wali AR, Steinberg JA, et al.: Epidemiology, natural history, and clinical presentation of large vessel ischemic stroke. Neurosurgery. 2019, 85:4-8. 10.1093/neuros/nyz042

8. Meyers PM, Schumacher HC, Connolly ES, Heyer EJ, Gray WA, Higashida RT: Current status of endovascular stroke treatment. Circulation. 2011, 123:2591-2601. 10.1161/CIRCULATIONAHA.110.971564

9. Rudin S, Bednarek DR, Hoffmann KR: Endovascular image-guided interventions (EIGIs). Med Phys. 2008, 35:301-309. 10.1118/1.2821702

10. Starke RM, Snelling B, Al-Mufti F, et al.: Transarterial and transvenous access for neurointerventional surgery: report of the SNIS Standards and Guidelines Committee. J Neurointerv Surg. 2020, 12:733-741. 10.1136/neurintsurg-2019-015573

11. Anjum I, Khan MA, Aadil M, Faraz A, Farooqui M, Hashmi A: Transradial vs. transfemoral approach in cardiac catheterization: a literature review. Cureus. 2017, 9:e1309. 10.7759/cureus.1309

12. Mitchell MD, Hong JA, Lee BY, Umscheid CA, Bartsch SM, Don CW: Systematic review and cost-benefit analysis of radial artery access for coronary angiography and intervention. Circ Cardiovasc Qual Outcomes. 2012, 5:454-462. 10.1161/CIRCOUTCOMES.112.965269

13. Rundek T, Sacco RL: Risk factor management to prevent first stroke . Neurol Clin. 2008, 26:1007-1045. 10.1016/j.ncl.2008.09.001

14. Balami JS, White PM, McMeekin PJ, Ford GA, Buchan AM: Complications of endovascular treatment for acute ischemic stroke: prevention and management. Int J Stroke. 2018, 13:348-361. $10.1177 / 1747493017743051$

15. Jolly SS, Yusuf S, Cairns J, et al.: Radial versus femoral access for coronary angiography and intervention in patients with acute coronary syndromes (RIVAL): a randomised, parallel group, multicentre trial. Lancet. 2011, 377:1409-1420. 10.1016/S0140-6736(11)60404-2

16. Haussen DC, Nogueira RG, DeSousa KG, et al.: Transradial access in acute ischemic stroke intervention. J Neurointerv Surg. 2016, 8:247-250. 10.1136/neurintsurg-2014-011519

17. Mendiz OA, Fava C, Lev G, Caponi G, Valdivieso L: Transradial versus transfemoral carotid artery stenting: a 16-year single-center experience. J Interv Cardiol. 2016, 29:588-593. 10.1111/joic.12342

18. Bertrand OF, Rao SV, Pancholy S, et al.: Transradial approach for coronary angiography and interventions: results of the first international transradial practice survey. JACC Cardiovasc Interv. 2010, 3:1022-1031. 10.1016/j.jcin.2010.07.013

19. Barros G, Bass DI, Osbun JW, et al.: Left transradial access for cerebral angiography. J Neurointerv Surg. 2020, 12:427-430. 10.1136/neurintsurg-2019-015386

20. Zussman BM, Tonetti DA, Stone J, et al.: Maturing institutional experience with the transradial approach for diagnostic cerebral arteriography: overcoming the learning curve. J Neurointerv Surg. 2019, 11:1235-1238. 10.1136/neurintsurg-2019-014920

21. Jo KW, Park SM, Kim SD, et al.: Is transradial cerebral angiography feasible and safe? A single center's experience. J Korean Neurosurg Soc. 2010, 47:332-337. 10.3340/jkns.2010.47.5.332

22. Chen SH, Snelling BM, Sur S, et al.: Transradial versus transfemoral access for anterior circulation mechanical thrombectomy: comparison of technical and clinical outcomes. J Neurointerv Surg. 2019, 11:874-878. 10.1136/neurintsurg-2018-014485

23. St Goar FG, Joye JD, Laird JR: Percutaneous arterial aortoiliac intervention. J Interv Cardiol. 2001, 14:533537. 10.1111/j.1540-8183.2001.tb00369.x

24. Darkhabani Z, Nguyen T, Lazzaro MA, et al.: Complications of endovascular therapy for acute ischemic stroke and proposed management approach. Neurology. 2012, 79:192-198. 10.1212/WNL.0b013e31826958e3

25. Levy EI, Kim SH, Bendok BR, et al.: Transradial stenting of the cervical internal carotid artery: technical case report. Neurosurgery. 2003, 53:448-452. 10.1227/01.neu.0000073995.81018.2b

26. Arora V, Patel M, Shroff AR: Complications of transradial cardiac catheterization and management . Interv Cardiol Clin. 2015, 4:193-202. 10.1016/j.iccl.2014.12.004

27. Bakoyiannis C, Economopoulos KP, Georgopoulos S, et al.: Transradial access for carotid artery stenting: a single-center experience. Int Angiol. 2010, 29:41-6.

28. Ganesh A, Goyal M: Thrombectomy for acute ischemic stroke: recent insights and future directions . Curr Neurol Neurosci Rep. 2018, 18:59. 10.1007/s11910-018-0869-8

29. Bendok BR, Przybylo JH, Parkinson R, et al.: Neuroendovascular interventions for intracranial posterior circulation disease via the transradial approach: technical case report. Neurosurgery. 2005, 56:e626. 10.1227/01.NEU.0000154820.28342.38 